\title{
COLOUR AND TEXTURE PROFILES OF BONELESS REESTRUCTURED DRY-CURED HAMS COMPARED TO TRADITIONAL HAMS
}

\author{
Marcela de Rezende Costa ${ }^{1}$; Walter Bergamin Filho ${ }^{1}$; Expedito Tadeu Facco Silveira ${ }^{2 *}$; Pedro \\ Eduardo de Felício ${ }^{1}$ \\ ${ }^{1}$ UNICAMP/FEA - Depto. de Tecnologia de Alimentos, C.P. 6121 - 13083-862 - Campinas, SP - Brasil. \\ ${ }^{2}$ ITAL - Centro de Pesquisa e Desenvolvimento de Carnes, Av. Brasil, 2880 - 17070-178 - Campinas, SP - Brasil. \\ *Corresponding author $\langle t$ facco@ital.sp.gov.br>
}

\begin{abstract}
Colour and texture, resultant of a complex process involving chemical, physical and enzymatic modifications, are important parameters for the acceptability of dry-cured hams. This study aimed to evaluate texture and colour instrumentally profiles of six types of dry-cured ham: two experimentally accelerated processed products, called CTC $3.5 \%$ and CTC $5.0 \%$ according to the initially added salt percentage; two imported (Spanish Serrano and Italian); and two Brazilian (Serrano type and Parma type) commercial products. The experimental process combined muscle-boning, transglutaminase addition, tumbling and moulding in stainless steel moulds, followed by drying and maturation. Evaluations were carried out using the Hunter colour system $\left(\mathrm{A}, 10^{\circ}\right)$ and TPA (Texture Profile Analysis). The samples differed in lightness (lighter products - CTCs), and in red colour (higher $a$ values - Italian and Serrano type). The more distinct texture profiles were seen in CTCs as compared to the Italian and Parma type samples, with the former having the highest values of hardness, springiness, cohesiveness and chewiness. The results showed the typical colour and texture characteristics of dry-cured hams, although each product had its own particularities likely due to differences in the raw material and processing techniques.
\end{abstract}

Key words: accelerated processing, maturation time, transglutaminase

\section{PERFIS DE COR E TEXTURA DE PRESUNTOS CRUS SEM OSSO E REESTRUTURADOS COMPARADOSAPRESUNTOS CRUSTRADICIONAIS}

\begin{abstract}
RESUMO: Cor e textura, resultantes de um processo complexo envolvendo modificações químicas, físicas e enzimáticas, são importantes parâmetros para a aceitabilidade de presuntos crus. Esse estudo visou avaliar os perfis instrumentais de textura e cor de seis tipos de presunto cru: dois experimentais, produzidos por processo acelerado, nomeados CTC 3,5\% e CTC 5,0\% de acordo com o percentual inicial de sal adicionado; dois importados (Serrano e Italiano); e dois produtos comerciais brasileiros (tipo Serrano e tipo Parma). O processo experimental combinou desossa dos pernis, adição de transglutaminase, tombamento e moldagem em formas de aço inoxidável, seguidos por secagem e maturação dos presuntos crus. As avaliações foram conduzidas utilizando o sistema de cor de Hunter $\left(\mathrm{A}, 10^{\circ}\right)$ e TPA (Análise de Perfil de Textura). As amostras diferiram em luminosidade (produtos mais claros - CTCs), e em coloração vermelha (valores de $a$ mais elevados - Italiano e tipo Serrano). Os perfis de textura mais distintos foram encontrados entre os produtos CTCs e os presuntos cru Italiano e tipo Parma, com os primeiros tendo os maiores valores de dureza, elasticidade, coesividade e mastigabilidade. Os resultados mostraram as características de cor e textura típicas de presuntos crus, embora cada produto tenha apresentado suas particularidades provavelmente devido a diferenças na matéria-prima e técnicas de processamento.

Palavras-chave: processamento acelerado, tempo de maturação, transglutaminase
\end{abstract}

\section{INTRODUCTION}

The traditional production of dry-cured ham lasts from 9 to 24 months, depending on the process- ing method and of the initial weight of the ham. Several procedures such as muscle boning (Kemp et al., 1980), tenderization (Marriot et al., 1985) and tumbling (Leak et al., 1984; Marriot et al., 1987) have been stud- 
ied to speed up the ageing process. Muscle boning had the most satisfactory processing time reduction without sensorial quality losses. Transglutaminase (TG) catalyzes the cross linking formation between protein molecules (Sharma et al., 2001). The TG utilized currently has microbiological origin and its use in frankfurters (Jiménez-Colmenero et al., 2005), beef protein gels (Dondero et al., 2006) and restructured pork products (Flores et al., 2007) has been studied recently. However, no study has been found about the use of TG on dry-cured ham processing.

The quality of the meat products is strongly affected by their textural properties, determined by technological and raw-material features. Several studies have evaluated the effect of different factors on the texture of dry-cured hams, such as genetic origin (Gou et al., 1995; Guerrero et al., 1996), sex and postmortem meat quality (Arnau et al., 1998; Tabilo et al., 1999), water content and water activity (Serra et al., 2005), $\mathrm{NaCl}$ content and proteolysis index (RuizRamírez et al., 2006). The dry-cured ham colour depends mainly on features of natural meat pigments and muscle structure. García-Esteban et al. (2003) carried out a study to optimize the instrumental colour evaluation of dry-cured hams. Different measurement systems of colour were tested. The Hunter system with A illuminant, independent of the observer angle, was considered the best condition for colour measurement in dry-cured ham.

The objectives of this study were: (i) to obtain instrumental texture and colour values of dry-cured hams produced by accelerated process (experimental products with 2 different levels of salt addition, 3.5 and 5\%), and by traditional methods (commercial products); (ii) to determine if the texture and colour of the experimental dry-cured hams were similar to some types of traditional products.

\section{MATERIAL AND METHODS}

Six types (four commercial and two experimental samples) of dry-cured ham samples were evaluated using ten units $(n=10)$ of each product. The commercial 12-month products an (Italian dry-cured ham; a Spanish Jamón Serrano; a Brazilian Parma type, and a Brazilian Serrano type) are the most representative dry-cured hams sold in the area where the research was carried out, and the experimental samples were prototypes developed in the Meat Research and Development Center (CTC) of the Institute of Food Technology (ITAL) in Campinas-SP, Brazil, according to the following system:

Thirty two pairs of hams obtained from a commercial line of pigs derived from Large White, Lan- drace and Duroc crossbreeding, specially developed for dry-cured ham production by a Brazilian company, were used to make dry-cured hams by accelerated processing. Skin and bones were removed and the main muscle groups (Semimembranosus, Biceps femoris, Quadriceps femoris, Semitendinosus, and Gluteus) were separated for processing. Apparent connective tissues and part of the fat were removed before the selected muscles were manually salted and placed on perforated shelves, which permitted brine draining, in a cold room held at $2.5 \pm 1.3^{\circ} \mathrm{C}$ and $83 \pm 2.7 \%$ relative humidity $(\mathrm{RH})$. Two salt levels were considered: muscle groups of 32 hams were salted with 3.5\% sodium chloride $(w / w)$, whereas muscle groups of the other 32 hams were salted adding 5.0\% sodium chloride $(\mathrm{w} / \mathrm{w})$. Both salt mixtures had sodium nitrite (200 $\left.\mathrm{mg} \mathrm{kg}{ }^{-1}\right)$ and sodium nitrate $\left(400 \mathrm{mg} \mathrm{kg}^{-1}\right)$. Added salt was computed for the muscle group of each single ham. Salting was completed when there was no visible salt on the muscle surface (7 days). After completion of salting, each muscle group was tumbled (7.5 $\left.\mathrm{rpm}, 0^{\circ} \mathrm{C}\right)$ during 2 minutes with $1 \%(\mathrm{w} / \mathrm{w}$, diluted $1: 4$ in water) transglutaminase (Activa TG-B ${ }^{\circledR}$, Ajinomoto Interamericana Ind. e Com. Ltda,) in aqueous solution, loaded into stainless steel moulds, and returned to the cold room $\left(3^{\circ} \mathrm{C}, 83 \% \mathrm{RH}\right)$ for one day to reinforce enzyme action, i.e. remake the muscle aggregation. Each formed ham was vacuum packed and loaded into mould for one more day. After removal of both moulds and vacuum packages, the hams were submitted to the drying stage in a cold room $\left(4.5 \pm 0.8^{\circ} \mathrm{C}, 71.6 \pm 1.7 \%\right.$ $\mathrm{RH})$ for 21 days. Thereafter, temperature was progressively increased, $1^{\circ} \mathrm{C}$ every $7-9$ days, until reaching $16^{\circ} \mathrm{C}$ (maturation phase), while RH was maintained at $70.0 \pm 2.0 \%$. At the end of this phase room temperature was increased to $27^{\circ} \mathrm{C}$ for two days. The complete process took four months, and then the final products were vacuum packed and maintained in a cold room $\left(4^{\circ} \mathrm{C}\right)$ until the beginning of the evaluation.

Six experimental dry-cured hams were randomly selected for texture and colour evaluations of $m$. biceps femoris, two of them being from the same carcass, one of each salt treatment. Commercial and experimental hams also were evaluated by other physicochemical parameters such as $\mathrm{pH}$ and chloride content (AOAC, 1998).

Colour parameters of the Hunter Lab System (lightness, redness/greenness, and yellowness/blueness) were determined with a portable Minolta CM508$\mathrm{d}$ spectrophotometer using A illuminant and $10^{\circ} \mathrm{ob}-$ server angle (García-Esteban et al., 2003). The evaluations were made in an air-conditioned room $\left(12^{\circ} \mathrm{C}\right)$, with four measurements in a central slice $(2 \mathrm{~cm}$ thick) of three dry-cured hams of each type. 
The dry-cured ham texture was determined using the Texture Profile Analysis technique or TPA (Bourne, 1978). The measurements were carried out using a TA-TX2 Texture Analyzer (Stable Micron Systems Ltda.) with a $5 \mathrm{~kg}$ load cell, as described by Tabilo et al. (1999). The samples were diced into cubes of $2 \mathrm{~cm}$. Four cubes obtained from a central slice (2 $\mathrm{cm}$ thick) of three dry-cured hams of each type were analyzed. Cubes were compressed axially in two consecutive cycles of $20 \%$ compression with a flat plunger $75 \mathrm{~mm}$ in diameter, moving at a constant speed of 1 $\mathrm{mm} \mathrm{s}^{-1}$. Data collection and calculation were carried through by the Texture Expert programme, version 1.11 (Stable Micron Systems Ltda.). From the TPA curves, the parameters of hardness, springiness, cohesiveness, adhesiveness and chewiness were determined.

The effect of type of dry-cured ham on texture and colour was determined by variance analysis (ANOVA) and Tukey's mean test $(P<0.05)$, using SAS.

\section{RESULTS AND DISCUSSION}

The most variable characteristic was lipid content (Table 1). So, based on this parameter, two groups could be established: CTCs and Serrano type, with the smallest fat content; and Serrano, Italian and Parma type, with the highest content.
The products differed $(P<0.05)$ in lightness (L) and redness (a), while yellowness (b) mean values were not different (Table 2). CTC products had the highest mean " $\mathrm{C}$ " value $(3.5 \%$ salt $=40.81 ; 5.0 \%$ salt $=39.09)$, which were different $(P<0.05)$ from Serrano, Serrano type, Italian, and Parma type hams (32.22; 32.53; 30.97 and 34.25 , respectively). Serrano type (15.53) and Italian (15.66) hams presented the highest mean "a" value $(P<0.05)$ compared to the other products $(P>0.05)$. The lightness and redness values found in this research are in agreement with those presented by García-Esteban et al. (2003), while the yellowness values are lower.

Colour of meat products such as dry-cured hams depend mainly on the concentration (Campo et al., 1991) and chemical state (Perez-Alvarez et al., 1998) of the meat pigments, and on the muscular structure (Hedrick et al., 1993). However, other ingredients and additives can affect the final colour. When nitrate and/or nitrite are used nitrosomyoglobin is formed, resulting in a bright red colour. Among the evaluated dry-cured hams, only the Serrano type did not have nitrificant addition. Besides the colour development they were also affected by the processing and storage conditions such as $\mathrm{pH}$, humidity and temperature (Flores, 1997).

Although salt can contribute to a decrease in lightness value, the water content is the more important factor according to Sanchez-Rodriguez et al.

Table 1 - Physicochemical parameters of the dry-cured hams.

\begin{tabular}{lcccc}
\hline Products & Total Solids & Lipids & Chlorides & $\mathrm{pH}$ \\
\hline CTC $3.5 \%, \mathrm{n}=10$ & $\%$ & $\% \mathrm{DM}$ & $\% \mathrm{DM}$ & $5.60 \pm 0.07^{\mathrm{cd}}$ \\
CTC $5.0 \%, \mathrm{n}=10$ & $51.35 \pm 1.59^{\mathrm{a}}$ & $7.10 \pm 2.10^{\mathrm{bc}}$ & $5.84 \pm 0.63^{\mathrm{ab}}$ & $5.56 \pm 0.05^{\mathrm{d}}$ \\
Serrano, $\mathrm{n}=10$ & $46.96 \pm 1.37^{\mathrm{b}}$ & $4.16 \pm 0.73^{\mathrm{c}}$ & $6.54 \pm 0.42^{\mathrm{a}}$ & $5.64 \pm 0.01^{\mathrm{cd}}$ \\
Serrano type, $\mathrm{n}=10$ & $51.35 \pm 0.16^{\mathrm{a}}$ & $11.06 \pm 0.02^{\mathrm{ab}}$ & $5.65 \pm 0.01^{\mathrm{b}}$ & $6.11 \pm 0.05^{\mathrm{a}}$ \\
Italian, $\mathrm{n}=10$ & $52.84 \pm 0.01^{\mathrm{a}}$ & $5.70 \pm 0.09^{\mathrm{c}}$ & $5.75 \pm 0.01^{\mathrm{b}}$ & $5.94 \pm 0.01^{\mathrm{b}}$ \\
Parma type, $\mathrm{n}=10$ & $51.17 \pm 0.16^{\mathrm{a}}$ & $13.65 \pm 0.13^{\mathrm{a}}$ & $5.53 \pm 0.01^{\mathrm{b}}$ & $5.73 \pm 0.07^{\mathrm{c}}$ \\
\hline
\end{tabular}

abcd Means \pm standard error, values with different letters in same column differ $(P<0.05)$. \% DM= composition on dry matter basis.

Table 2 - Colour instrumental profiles of the dry-cured hams.

\begin{tabular}{lccc}
\hline Products & $\mathrm{L}$ & $\mathrm{a}$ & $\mathrm{b}$ \\
\hline CTC $3.5 \%, \mathrm{n}=10$ & $40.81 \pm 0.68^{\mathrm{a}}$ & $12.03 \pm 0.44^{\mathrm{b}}$ & $2.43 \pm 0.13^{\mathrm{a}}$ \\
CTC $5.0 \%, \mathrm{n}=10$ & $39.09 \pm 0.94^{\mathrm{a}}$ & $10.98 \pm 0.59^{\mathrm{b}}$ & $2.04 \pm 0.16^{\mathrm{a}}$ \\
Serrano, $\mathrm{n}=10$ & $32.22 \pm 0.59^{\mathrm{b}}$ & $12.00 \pm 0.31^{\mathrm{b}}$ & $2.56 \pm 0.26^{\mathrm{a}}$ \\
Serrano type, $\mathrm{n}=10$ & $32.53 \pm 0.80^{\mathrm{b}}$ & $15.53 \pm 0.60^{\mathrm{a}}$ & $2.52 \pm 0.18^{\mathrm{a}}$ \\
Italian, $\mathrm{n}=10$ & $30.97 \pm 1.39^{\mathrm{b}}$ & $15.66 \pm 0.61^{\mathrm{a}}$ & $2.80 \pm 0.16^{\mathrm{a}}$ \\
Parma type, $\mathrm{n}=10$ & $34.25 \pm 1.05^{\mathrm{b}}$ & $12.08 \pm 0.41^{\mathrm{b}}$ & $2.38 \pm 0.23^{\mathrm{a}}$ \\
\hline
\end{tabular}

${ }^{\mathrm{ab}}$ Means \pm standard error, values with different letters in same column differ $(P<0.05)$. L $=$ lightness; $\mathrm{a}(+)=$ redness; $\mathrm{b}(+)=$ yellowness. 
Table 3 - Texture instrumental profiles of the dry-cured hams.

\begin{tabular}{|c|c|c|c|c|c|}
\hline Products & Hardness & Adhesiveness & Springiness & Cohesiveness & Chewiness \\
\hline & g & gxs & & & \\
\hline CTC $3.5 \%, n=10$ & $1729.3 \pm 25.26^{b}$ & $132.4 \pm 7.25^{\mathrm{a}}$ & $0.86 \pm 0.0^{\mathrm{a}}$ & $0.77 \pm 0.01^{\mathrm{ab}}$ & $1145.6 \pm 24.94^{\mathrm{ab}}$ \\
\hline CТC $5.0 \%, \mathrm{n}=10$ & $2654.0 \pm 146.85^{\mathrm{a}}$ & $27.6 \pm 9.06^{\mathrm{a}}$ & $0.80 \pm 0.01^{\mathrm{ab}}$ & $0.80 \pm 0.01^{\mathrm{a}}$ & $1701.5 \pm 107.82^{\mathrm{a}}$ \\
\hline Serrano, $\mathrm{n}=10$ & $1932.8 \pm 88.13^{\mathrm{ab}}$ & $26.2 \pm 5.25^{\mathrm{a}}$ & $0.75 \pm 0.03^{\mathrm{abc}}$ & $0.69 \pm 0.02^{b c}$ & $1001.0 \pm 76.73^{b}$ \\
\hline Serrano T., $\mathrm{n}=10$ & $2001.7 \pm 245.84^{\mathrm{ab}}$ & $23.1 \pm 6.12^{\mathrm{a}}$ & $0.73 \pm 0.01^{\mathrm{bc}}$ & $0.69 \pm 0.03^{b c}$ & $1058.7 \pm 180.25^{\mathrm{b}}$ \\
\hline Italian, $\mathrm{n}=10$ & $824.1 \pm 29.10^{c}$ & $9.2 \pm 15.85^{\mathrm{a}}$ & $0.65 \pm 0.02^{\mathrm{c}}$ & $0.63 \pm 0.01^{\mathrm{c}}$ & $339.5 \pm 23.84^{c}$ \\
\hline Parma T., $\mathrm{n}=10$ & $1351.2 \pm 58.92^{\mathrm{bc}}$ & $19.5 \pm 4.33^{\mathrm{a}}$ & ${ }^{\mathrm{a}} 0.69 \pm 0.02^{\mathrm{bc}}$ & $0.65 \pm 0.02^{\mathrm{c}}$ & $606.9 \pm 39.98^{\mathrm{bc}}$ \\
\hline
\end{tabular}

${ }^{\text {abc }}$ Means \pm standard error, values with different letters in same column differ $(P<0.05)$.

(2001). High dehydration during the processing contributes to the concentration of the muscle pigments (García-Esteban et al., 2003). Thus, absence of nitrificants combined to low moisture content can have resulted in darker colour (low "L" and high "a") in the Serrano type ham. On the other hand, a higher moisture content and nitrificant addition in the CTC hams led to products that had greater lightness and lower redness.

In the texture instrumental profiles all drycured hams (Table 3$)$ showed differences $(P<0.05)$ in the parameters except for adhesiveness that had a variation from 19.46 gxs (Parma type) to 69.23 gxs (Italian dry-cured ham).

CTC $5.0 \%$ dry-cured ham had more distinct textural profiles in relation to the Italian hams while the latter were very similar in relation to the Parma Type, $(P>0.05)$. Italian dry cured hams came up with the lowest hardness, springiness, cohesiveness and chewiness and CTC $5.0 \%$ presented the highest hardness, cohesiveness and chewiness. CTC 3.5\%, Serrano and Serrano Type showed similar behavior for some texture characteristics (hardness, adhesiveness, cohesiveness and chewiness, $P>0.05$ ).

In dry-cured ham, texture is a characteristic directly related to the muscle structure, especially related to the degradation of myofibrillar protein and collagen as well as to the intramuscular fat content and drying rate (Toldrá, 1998). Characteristics of fresh ham (conformation, fat thickness, and fat content) from different genetic origins are also responsible for the differences found in dry-cured ham textures (Gou et al., 1995; Guerrero et al., 1996). Other aspects, such as intrinsic enzymatic activity of ham (Parolari et al., 1994; Parreño et al., 1994) or meat pH (Arnau et al., 1998; Buscailhon et al., 1994) also contribute to the texture properties.

In this study the moisture content does not seem to have had a consistent effect over the textural attributes, probably due the influence of other factors such as fat content and maybe because of the small difference in water content among the samples. Ruiz-Carrascal et al. (2000) also found no significant relationship between the degree of dehydration (water content) and the sensory textural characteristics (hardness, dryness and juiciness) in Iberian dry-cured hams.

Ruiz-Ramírez et al. (2006) observed that drycured hams with higher proteolysis show lower hardness and higher cohesiveness and springiness, especially at low water content. As proteolysis occurs during all the maturation stage, the longer this stage is, the higher is the proteolysis index. Thus, it would be expected that the CTCs had the lowest cohesiveness and springiness values, but actually they present the highest values. Transglutaminase affects the functional properties of proteins, specially the binding capacity, so the use of TG in the CTCs hams could be responsible for enhancing their springiness and cohesiveness. On the other hand, a shorter ageing time in these products must have reduced the action of the proteolytic enzymes on the muscle structure as well as the final $\mathrm{pH}$ of the final products. Thus the short ageing time combined to lower fat content ended up resulting in higher hardness and chewiness in the CTCs than in Italian and Parma type hams, which had longer processing times and higher fat content.

\section{ACKNOWLEDGEMENTS}

To FAPESP for the resources that supported this study, and to CNPq for the scholarships granted to the two first authors.

\section{REFERENCES}

ASSOCIATION OF OFFICIAL ANALYTICAL CHEMISTS AOAC. Official methods of analysis. 16ed. Gaithersburg: AOAC, 1998. 23p.

ARNAU, J.; GUERRERO, L.; SARRAGA, C. The effect of green ham $\mathrm{pH}$ and $\mathrm{NaCl}$ concentration on characteristics of dry-cured ham. Journal of the Science of Food and Agriculture, v.77, p.387-392, 1998.

BOURNE, M.C. Texture profile analysis. Food Technology, v.32, p.62-66, 1978 
BUSCAILHON, S.; BERDAGUE, J.L.; GANDEMER, G.; TOURAILlE, C.; MONIN, G. Effects of initial $\mathrm{pH}$ on compositional changes and sensory traits of French dry-cured ham. Journal of Muscle Foods, v.5, p.257-270, 1994.

CAMPO, A.; PÉREZ-ALVAREZ, J.A.; SAYAS, M.E.; ARANDA, V. Caracterización física y fisicoquímica del jamón curado: influencia sobre el color en la etapa de maduración. In: FITO, P.; SERRA, J.; HERNÁNDEZ, E.; VIDAL, D. (Ed.). Anales de investigación del master en ciência e ingeniería de alimentos. Valencia: Universidad Politécnica de Valencia, 1991. v.1, p.921-937.

DONDERO, M.; FIGUEROA, V.; MORALES, X.; CUROTTO, E. Transglutaminase effects on gelation capacity of thermally induced beef protein gels. Food Chemistry, v.99, p.546-554, 2006.

FLORES, J. Mediterranean vs. northern European meat products: processing technologies and main differences. Food Chemistry, v.59, p.505-510, 1997.

FLORES, N.C.; BOYLE, E.A.E.; KASTNER, C.L. Instrumental and consumer evaluation of pork restructured with Activa ${ }^{\mathrm{TM}}$ or with Fibrimex ${ }^{\mathrm{TM}}$ formulated with and without phosphate. Food Science and Technology, v.40, p.179-185, 2007.

GARCÍA-ESTEBAN, M.; ANSORENA, D.; GIMENO, O.; ASTIASARÁN, I. Optimization of instrumental colour analysis in dry-cured ham. Meat Science, v.63, p.287-292, 2003.

GOU, P.; GUERRERO, L.; ARNAU, J. Sex and breed cross effects on dry-cured ham characteristics. Meat Science, v.40, p.2131,1995

GUERRERO, L.; GOU, P.; ALONSO, P.; ARNAU, J. Study of the physico-chemical and sensorial characteristics of dry-cured ham in three pig genetic types. Journal of the Science of Food and Agriculture, v.70, p.526-530, 1996.

HEDRICK, H.B.; ABERLE, E.D.; FORREST, J.C.; JUDGE, M.D.; MERKEL, R.A. Principles of meat science. 3.ed. Dubuque: Kendall-Hunt, 1993. 354p.

JIMÉNEZ-COLMENERO, F.; AYO, M.J.; CARBALLO, J. Physicochemical properties of low sodium frankfurter with added walnut: effect of transglutaminase combined with caseinate, $\mathrm{KCl}$ and dietary fibre as salt replacers. Meat Science, v.69, p.781788, 2005.

KEMP, J.D.; ABIDOYE, D.F.O.; LANGLOIS, B.E.; FRANKLIN, J.D.; FOX, J.D. Effect of curing ingredients, skinning and boning on yield, quality and microflora of country hams. Journal of Food Science, v.45, p.174-177, 1980.

LEAK, F.W.; KEMP, J.D.; LANGLOIS, B.E.; FOX, J.D. Effect of tumbling and tumbling time on quality and microflora of drycured hams. Journal of Food Science, v.49, p.695, 1984.

MARRIOT, N.G.; GRAHAM, P.P.; SHAFFER, C.K.; PHELPS, S.K. Accelerated production of dry-cured hams. Meat Science, v.19, p.53, 1987.
MARRIOT, N.G.; KELLY, R.F.; SHAFFER, C.K.; GRAHAM, P.P.; BOLLING, J.W. Accelerated dry curing of hams. Meat Science, v. 15, p. 51,1985

PAROLARI, G.; VIRGILI, R.; SCHIVAZAPPA, C. Relationship between Cathepsin B activity and compositional parameters in dry-cured hams of normal and defective texture. Meat Science, v.38, p.117-122, 1994.

PARREÑO, M.; CUSSÓ, R.; GIL, M.; SARRAGA, C. Development of cathepsins B, L and $\mathrm{H}$ activities and cystatin-like activity during two different manufacturing processes of Spain dry-cured ham. Food Chemistry, v.49, p.15-21, 1994.

PEREZ-ALVAREZ, J.A.; SAYAS-BARBERA, M.E.; FERNANDEZLOPEZ, J.; GAGO-GAGO, M.A.; PAGAN-MORENO, M.J.; ARANDA-CATALA, V. Spanish dry-cured ham aging process: colour characteristics. In: INTERNATIONAL CONGRESS OF MEAT SCIENCE AND TECHNOLOGY, 44, Barcelona, 1998. Proceedings. Barcelona, 1998. p.984-985.

RUIZ-CARRASCAL, J.; VENTANAS, J.; CAVA, R.; ANDRÉS, A.; GARCÍA, C. Texture and appearance of dry cured ham as affected by fat content and fatty acid composition. Meat Science, v.33, p.91-95, 2000.

RUIZ-RAMÍREZ, J.; ARNAU, J.; SERRA, X.; GOU, P. Effect of $\mathrm{pH}_{24}, \mathrm{NaCl}$ content and proteolysis index on the relationship between water content and texture parameters in biceps femoris and Semimembranosus muscles in dry-cured ham. Meat Science, v.72, p.185-194, 2006

SANCHEZ-RODRÍGUEZ, M.E.; PÉREZ-ALVAREZ, J.A.; ALONSO-MATEOS, A.; GANDARA-MERINO, J.M.; SAYASBARBERA, M.E. Parâmetros de color del Jamón Ibérico de Bellota D.O.: Guijuelo al final del periodo de maduración. Alimentaria, n.321, p.33-39, 2001.

SHARMA, R.; LORENZEN, P.C.; QVIST, K.B. Influence of transglutaminase treatment of skim milk on the formation of $\varepsilon$-( $\gamma$-glutamyl)lysine and the susceptibility of individual proteins towards crosslinking. International Dairy Journal, v.11, p.785-793, 2001.

TABILO, G.; FLORES, M.; FISZMAN, S.M.; TOLDRÁ, F. Postmortem meat quality and sex affect textural properties and protein breakdown of dry-cured ham. Meat Science, v.51, p.255260, 1999.

TOLDRÁ, F. Desarrollo da las características de textura y flavor: contribución enzimática. In: INTERNATIONAL CONGRESS OF MEAT SCIENCE AND TECHNOLOGY, 44, Barcelona, 1998. Simposio Especial. Barcelona, 1998. p.42-54.

Received March 16, 2006

Accepted October 15, 2007 